\title{
Feminisme dan Kebebasan Perempuan Indonesia dalam Filosofi
}

\author{
Dhiyaa Thurfah llaa ${ }^{1}$ \\ ${ }^{1}$ Prodi IImu Komunikasi, Universitas Indonesia Jakarta, Indonesia \\ E-mail: dhiyaa.thurfah@ui.ac.id ${ }^{1}$
}

\begin{abstract}
Abstrak
Kebebasan seharusnya adalah hal yang absolut untuk dimiliki seluruh individu terlepas dari jenis kelaminnya. Namun, sejak terciptanya masyarakat, kebebasan perempuan selalu dibatasi. Hak dan kesempatan laki-laki hingga kini masih tidak setara dengan perempuan. Perempuan Indonesia sejak dahulu sudah mulai memperjuangkan kesetaraannya. Didorong dengan berkembangnya zaman dan globalisasi, perjuangan perempuan Indonesia akan kesetaraan semakin berkembang. Gerakan feminisme bertujuan untuk membantu perempuan memperjuangkan hak dan kebebasan perempuan di masyarakat Indonesia yang masih dominan patriarki. Tujuan penelitian ini yaitu untuk memahami serta mengetahui filosofi dari feminisme dan kebebasan perempuan. Metode penelitian yang digunakan adalah studi literatur deskriptif dan interpretif. Hasil studi literatur menunjukkan bahwa beberapa ahli filosofis feminis menjelaskan bahwa guna mencapai kesetaraan, laki-laki dan perempuan harus diberikan pendidikan yang sama, serta tidak diberi perlakuan yang diskriminatif. Ahli filosofis feminis lainnya meyakini bahwa perempuan dan laki-laki hakikatnya berbeda, namun memiliki hak yang sama dalam hal kebebasan. Kebebasan memiliki dua jenis, yakni kebebasan positif dan negatif. Keduanya merupakan hal yang bertolak belakang yang perlu dikritisi lebih lanjut, serta masih perlu dipertimbangkan sebab dan akibat yang ditimbulkan bagi perempuan, khususnya di Indonesia.
\end{abstract}

Kata Kunci: feminisme; filosofi feminisme; kebebasan; perempuan Indonesia.

\begin{abstract}
Liberty should be an absolute aspect to every human beings, regardless their gender. Ever since the creations of society, women's right has always been limited. Their rights and liberty is still unequal to men's rights and liberty. Indonesian women started their fight for equality since forever, triggered by the world's evolution and globalization, Indonesian women's fight for their equal rights and liberty started to flourish. Feminism is a movement that help women to fight their equal rights and liberty in Indonesia which society still dominated by patriarchy. This study aims to understand the philosophy of feminism and women's liberty. The method used in this study was descriptive and interpretative literature analysis. The results of this study showed that some feminist philosophers explain that in order to achieve equality, either men or women should receive the same education, and not to be treated discriminatively. Some other feminist philosophers believe that men and women are different, but in the context of human rights and liberty, they are all the same. Liberty has two notions, positive liberty and negative liberty, which is contradicted in one another. These liberties need to be criticized further, and consider the effect on women in Indonesia.
\end{abstract}

Keyword: feminism; feminism philosophy; freedom; Indonesian women.

\section{Pendahuluan}

Sejak dahulu, kebebasan merupakan sesuatu yang selalu diperjuangkan oleh manusia. Beberapa kritikus menyatakan bahwa kebebasan merupakan nilai yang sangat penting dalam masyarakat, dan semua manusia berhak mendapatkan kebebasan tanpa memandang status ekonomi dan sosial mereka (Harrison \& Boyd, 2003). Kebebasan dilihat dari kacamata filsafat merupakan hal yang penting. Filsafat kebebasan berarti kebebasan boleh didapatkan oleh manusia sebagai sebuah jalan untuk mendapatkan kebenaran. Dalam pemahamannya, dapat diartikan bahwa kebebasan harus diaktualkan dalam ruang etika, di mana manusia bebas harus menjalani dan berbagi dalam menjalankan kebebasannya. Kebebasan merupakan salah satu isu 
penting dalam filsafat. Kebebasan memiliki wilayah persoalan yang luas dan dapat berkaitan dengan persoalan moralitas, politik, ekonomi, psikologi, hukum, bahkan agama (Tutupary, 2016).

Dalam dunia sosial, nilai dan moral dalam masyarakat sangat memengaruhi bentuk hukum dan batasan kebebasan. Namun, tidak semua batasan kebebasan terdapat di dalam hukum tertulis. Nilai norma dalam masyarakat seperti pendapat minoritas, pengucilan, dan ketidaksetujuan memiliki pengaruh besar terhadap kebebasan individu. Hal tersebut dapat menjadi sumber penindasan, paksaan, dan batasan terhadap kebebasan individu, meskipun tidak terdapat dalam hukum tertulis. Contohnya dapat berupa perundungan atau pengucilan dalam masyarakat, ketika seseorang dianggap aneh, tidak biasa, atau tidak sesuai dengan ekspektasi masyarakat. Ekspektasi masyarakat dalam dunia sosial merupakan elemen yang berperan penting dalam pembatasan kebebasan individu, khususnya bagi kaum perempuan yang kebebasannya sampai saat ini masih sering dibatasi oleh ekspektasi masyarakat.

Kebebasan kaum perempuan sangat dibatasi sejak dahulu hingga kini, terlebih lagi dalam masyarakat patriarki. Menurut Therborn (2004), sejak awal masyarakat selalu bersifat patriarki, tanpa pengecualian. Walby (1990) menyatakan, patriarki merupakan sebuah sistem stuktur dan praktik sosial di mana laki-laki mendominasi, menindas, dan mengeksploitasi perempuan, serta meyakini bahwa laki-laki selalu berada dalam posisi yang dominan dan perempuan berada dalam posisi subordinat. Pada abad ke-18 dan 19, masyarakat yang saat itu cenderung patriarki berpendapat bahwa perempuan memiliki sifat yang tidak rasional, rapuh, dan tidak dapat berfikir secara mandiri. Masyarakat saat itu beranggapan bahwa perempuan layaknya seekor binatang peliharaan yang dimiliki oleh tuannya, dan sebagai binatang wanita perlu menunjukkan kepatuhan kepada pemiliknya yaitu suaminya (Weitz, 2003).

Untuk memperjuangkan kebebasan dan keadilan bagi perempuan, gerakan feminisme muncul. Feminisme merupakan sebuah pemikiran yang memandang bahwa perempuan dan lakilaki memiliki hak yang sama dalam politik, sosial, seksual, intelektual, dan ekonomi. Feminisme mecakup gerakan, teori, filosofi, dan segala hal yang berhubungan dengan masalah kesetaraan gender yang bertujuan untuk memberikan keadilan kepada perempuan. Menurut Kristeva (1986), terdapat tiga gelombang atau era feminisme. Gelombang pertama feminisme berfokus pada ketidakadilan sosial dan hak-hak politik yang setara antara perempuan dan laki-laki, mencakup juga pendidikan dan kemandirian. Gelombang ini ditandai dengan adanya feminisme liberal. Gelombang kedua feminisme berfokus pada beberapa masalah seperti ketidaksetaraan dalam pekerjaan, hak dalam seksualitas, keluarga, dan reproduktif. Gelombang ini ditandai dengan munculnya feminisme radikal. Gelombang ketiga feminisme mencakup globalisasi kesetaraan gender, dan seksualisasi perempuan, yang termasuk feminisme postmodern.

Hasil dari gerakan feminisme, perempuan mulai diberikan kesempatan yang sama dalam hal edukasi dan politik, serta keadilan dalam mendapatkan hak-haknya. Selain itu, kebebasan perempuan makin terbuka lebar seiring dengan perkembangan zaman. Gerakan feminisme tentu memberikan dampak positif bagi para perempuan. Seringkali masyarakat hanya memandang feminisme sebagai gerakan penolakan dan pernyataan protes akan patriarki yang merugikan para feminis. Namun, feminisme memiliki nilai dan makna filosofis yang bukan sekadar demonstrasi atau protes semata mengenai hak dan kebebasan perempuan. Penulis pun tertarik dalam mengetahui makna feminisme dan kebebasan perempuan khususnya di Indonesia dalam kacamata beberapa teori filosofi yang dikembangkan oleh ahli filsafat ternama, serta ingin mengetahui pentingnya feminisme di Indonesia.

\section{Metode}

Penulisan artikel jurnal ini menggunakan studi literatur, yaitu mempelajari beberapa sumber literatur mengenai filsafat feminisme dan kebebasan yang terdapat dalam buku, jurnal, ataupun artikel menurut berbagai ahli filsafat. Unsur-unsur metode yang digunakan yaitu sebagai berikut. Pertama, deskripsi. Metode ini digunakan untuk memberikan uraian mengenai beberapa teori atau konsep feminisme dan kebebasan dalam pandangan beberapa ahli filsafat. Kedua, interpretasi. Metode ini digunakan untuk memahami konsep filosofis feminisme dan kebebasan, menginterpretasikan nilai dan maknanya, serta mengaitkannya dalam kehidupan perempuan di Indonesia. 


\section{Hasil dan Pembahasan \\ a. Mary Wollstonecraft}

Mary Wollstonecraft adalah seorang filosofis dari abad ke-18 dan seorang feminis yang argumentasinya dikategorikan dalam kelompok feminisme liberal. Mary Wollstonecraft adalah sosok yang penuh semangat dalam menyampaikan pendapatnya dalam konteks edukasi dan kesetaraan sosial. la menyampaikan argumennya dalam bukunya yang sangat populer bagi kalangan feminis, A Vindication of the Rights of Women (1792). Wollstonecraft menghabiskan seumur hidupnya menjadi seorang pengajar bagi perempuan muda, hingga menginspirasinya dalam Thoughts on the Education of Daughters (1787). Kini ia dianggap sebagai pahlawan feminisme bagi kaum wanita. Wollstonecraft berargumen bahwa terdapat kesenjangan sosial antar jenis kelamin, dalam hal pendidikan serta pengalaman. Menurut Wollstonecraft (1995), kesenjangan ini merupakan rintangan atau penghalang dalam pembentukan masyarakat modern. Menurutnya, tanpa adanya keadilan social, tidak akan ada kehidupan sosial. Wollstonecraft menuntut adanya perubahan dan transformasi dari pandangan konservatif masyarakat. Protesnya mencakup hak dan kebebasan wanita, yang dimana dikuasai oleh rezim gender dari masyarakat. Sebagai contoh, masyarakat selalu memandang laki-laki sebagai seseorang yang rasional, sedangkan perempuan sebagai seseorang yang sentimental.

Wollstonecraft beragumen bahwa untuk memiliki kekuatan, seorang perempuan harus jujur, cerdas, dan mandiri. Pandangan Wollstonecraft akan nilai perempuan sering direndahkan dalam novel, literatur, dan sistem edukasi selama berabad-abad. Menurut Wollstonecraft, lakilaki dan perempuan merupakan individu dengan pemikiran yang sama jika diberikan pendidikan yang setara. Adanya ketidaksetaraan tersebutlah yang menyebabkan kesenjangan dan perbedaan antara laki-laki dan perempuan. Dalam konteks filosofis menurut Wollstonecraft, seluruh individu memiliki nilai moral yang setara, terlepas dari diskriminasi jenis kelamin, ras, kepercayaan, maupun agamanya. Individu hanya dibedakan berdasarkan kepribadian, keterampilan, dan kepandaiannya. Dengan demikian, maka hak dan kekebasan tiap individu merupakan hal yang mutlak dimiliki, baik perempuan maupun laki-laki. Tanpa kebebasan, tidak akan ada kebijakan. Menurut Wollstonecraft (1989) kebebasan merupakan akar dari kebijakan, wanita tanpa kebebasan hanya akan menimbulkan kecacatan dalam masyarakat.

Wollstonecraft menyanggah argumen bahwa perempuan merupakan sosok yang sentimental. Perbedaan antara perempuan dan laki-laki menurutnya dalam masyarakat dihasilkan dari pendidikan yang mereka dapatkan. Alasan mengapa masyarakat selalu menganggap laki-laki merupakan seseorang yang rasional, sedangkan perempuan merupakan seseorang yang sentimental, semata-mata dikarenakan didikan yang mereka terima. Laki-laki dididik untuk selalu bertindak rasional, sedangkan perempuan diberikan pendidikan yang mendukung kefeminisan dan kesentimentalan karakter mereka, yang membuat nilai tersebut seolah merepresentasi perempuan secara permanen. Karena hal tersebut, maka terciptalah peran gender dan tradisi yang sebenarnya merupakan produk artifisial dari pendidikan yang ditanamkan oleh masyarakat. Karakter yang maskulin atau feminin merupakan hasil konstruksi dari produk tersebut.

Wollstonecraft (1989) berargumen bahwa moralitas dan nilai seseorang tidak bergantung pada jenis kelaminnya. Beliau meyakini, laki-laki maupun perempuan hakikatnya adalah sama, meskipun memiliki peran dan tugas yang berbeda, bahwa perempuan dan laki-laki memiliki akal yang sama. Dengan memberikan perempuan kesempatan yang sama, kesetaraan hak, dan kebebasan dalam hal politik, sosial, serta ekonomi, argumen Wollstonecraft mungkin merupakan argumen yang tepat. Hanya saja, apakah teori Wollstonecraft berlaku pada masyarakat Indonesia yang memiliki akar pemikiran patriarki yang kuat, masih dapat dipertanyakan.

Perjuangan perempuan Indonesia untuk mendapatkan pendidikan yang setara dengan laki-laki sudah mulai sejak lama, dan memiliki titik terang dengan perjuangan R.A. Kartini. Kartini sendiri merupakan pejuang emansipasi, kesetaraan, dan hak perempuan di Indonesia. Perempuan di Indonesia saat ini telah memiliki kesempatan dalam menerima edukasi yang setara dengan laki-laki di Indonesia. Namun, hal ini mungkin belum lazim ditemukan di pelosok-pelosok pedalaman Indonesia. Perempuan di Indonesia saat ini juga telah memiliki hak dalam bidang legal dan politik yang sama dengan laki-laki. Berbeda hal dengan hak-hak dan norma-norma sosial yang masih banyak yang mendiskriminasi kaum perempuan, bahkan merugikan perempuan. Seharusnya, dengan edukasi yang sudah setara, akal dan benak yang setara, seluruh diskriminasi dalam hak dan kebebasan perempuan sudah tidak ada. Walaupun begitu, nyatanya masih banyak masyarakat yang membedakan perempuan dan laki-laki dalam konteks sosial. 


\section{b. Simone de Beauvoir}

Simone de Beauvoir merupakan tokoh feminisme ternama pada abad ke-20 dan merupakan ahli filsafat asal Perancis. Sebelum menjadi seorang feminis, Beauvoir pertama-tama merupakan seorang filsuf. Dalam Lianawati (2021), disebutkan bahwa Beauvoir merupakan filsuf perempuan yang selalu ada di bayang-bayang filsuf laki-laki lainnya. Tak peduli seberapa banyak karyanya dan seberapa suksesnya ia sebagai filsuf, itu semua tidak dapat melebihi para filsuf laki-laki khususnya di Perancis. Beauvoir mengambil pilihan hidupnya berdasarkan nilai, prinsip, dan pemikiran filosofisnya, dan membentuk jalan kehidupan yang mempengaruhi Kembali pikirannya. Bagi Beauvoir, kehidupan adalah investasi tanpa henti. Maka sebagai seorang feminis pun ia termasuk sebagai feminis eksistensial. Beauvoir memiliki argumentasi yang kuat dalam hal kebebasan perempuan. Sejak dahulu, laki-laki selalu diberikan kebebasan dalam menentukan nasibnya dan memilih jalan hidupnya, sedangkan perempuan hanya memiliki pilihan terbatas, bahkan terkadang hidupnya dipilihkan oleh orang lain. Menurut Beauvoir, perempuan harus diberikan kebebasan yang sama dengan kebebasan yang diberikan pada laki-laki, namun hal ini bukan berarti perempuan dan laki-laki merupakan individu yang sama.

Dalam bukunya Le Deuxieme Sexel atau The Second Sex (1949), Simone de Beauvoir menegaskan bahwa perempuan dan laki-laki adalah makhluk yang berbeda, namun seluruh pandangan terhadap dunia nampaknya selalu diceritakan dalam sudut pandang para lelaki. Beauvoir juga merasa, dengan dominannya representasi dunia yang hanya dari kacamata lakilaki, terciptalah standar-standar terhadap perempuan yang merupakan hasil dari opini laki-laki. Dengan terciptanya standar tersebut, terbentuklah "peran gender" terhadap kaum perempuan yang secara tidak langsung memaksa perempuan sebagai seorang ibu, seorang istri, serta seorang wanita terhormat, bahwa perempuan haruslah memiliki sifat keibuan, lemah, lembut, dan rapuh. Dengan sifat masyarakat yang masih dominan patriarki, tidak mengherankan bahwa masyarakat Indonesia masih banyak yang menganggap peran gender dan steriotipe adalah hal yang wajar.

Beauvoir sangat menolak hal tersebut dan mendorong para perempuan untuk menemukan jati dirinya melalui kebebasan, tanpa adanya paksaan atau standar yang diberikan kepadanya. Beauvoir meyakini, meskipun perempuan dan laki-laki berbeda seluruh individu memiliki hak yang sama dalam seluruh aspek kehidupan. Seringkali, pemikiran mengenai stereotip perempuan yang sempurna sudah tertanam dalam pikiran perempuan Indonesia, yang seluruh hidupnya selalu didikte apa yang harus dan tidak boleh dilakukan. Perempuan seharusnya memiliki kesadaran untuk menentukan kebebasannya, perempuan berhak untuk dapat bekerja sesuai keinginannya, berhak untuk menempuh pendidikan setinggi-tingginya, dan berhak menolak dirinya untuk dijadikan objek (Prameswari, dkk., 2019). Namun, tidak semua perempuan memiliki kesempatan yang sama untuk mengklaim kebebasannya.

Beauvoir mengaku sebagai pejuang feminis eksistensial. Dalam feminisme eksistensal, kebebasan merupakan subjektivitas, di mana "manusia adalah kebebasan itu sendiri". Menurut Prameswari, dkk. (2019), contoh perjuangan perempuan menurut feminisme eksistensial yaitu misalkan seorang perempuan yang mendapatkan kekerasan oleh suaminya, memiliki kebebasan untuk melawan suaminya, dan bebas memilih untuk menggugat cerai atau tidak, kemudian misalkan seorang perempuan dilecehkan oleh seorang rekan kerja laki-laki, bebas melakukan perlawanan langsung terhadap laki-laki tersebut. Di Indonesia, sudah tidak asing lagi istilah "catcalling" yang merupakan pelecehan secara verbal yang biasanya ditujukan kepada perempuan. Saking tidak asingnya, beberapa orang menganggap catcalling merupakan hal biasa dan tidak perlu diributkan. Namun pejuang feminis eksistensial mendukung para perempuan yang berani mengkonfrontasi pelaku catcalling-nya. Sebagai contoh, Miss International 2017, Kevin Liliana, yang sering menerima perlakuan catcalling memutuskan untuk menghadapi pelakunya. Sikap tersebut merupakan contoh perjuangan kebebasan dalam ranah feminisme.

\section{c. Isaiah Berlin}

Isaiah Berlin merupakan pemikir filosofi dan sejarawan asal Inggris yang salah satu objek utama dalam pemikirannya adalah konsep kebebasan. la dianggap sebagai salah satu penemu konsep displin sejarah intelektual. Setelah Perang Dunia ke-2, minat Berlin semakin meluas dari sains politik, teori politik, kebebasan intelektual, hingga konsep kebebasan. Berlin dikenal sebagai sosok yang brilian dan tak ragu dalam menyampaikan pendapatnya akan liberalisme dan pluralisme, serta pendapatnya akan orang-orang dan berbagai ide yang cemerlang yang banyak ia sampaikan dalam karyanya. Karyanya, Two Concepts of Liberty (1958), berkontribusi besar dalam pandangan dunia akan kebebasan dari kacamata politik. Selain itu, salah satu karyanya 
yang berjudul Four Essays on Liberty (1969) juga menguak mengenai masalah kebebasan dalam kehidupan sosial. Berlin mengemukakan bahwa terdapat dua macam kebebasan, yakni kebebasan positif dan kebebasan negatif (Berlin, 2008). Menurutnya dua macam kebebasan itu bertentangan atau berkontradiksi satu sama lain. Kebebasan negatif menurut Berlin yaitu merupakan jawaban atas pertanyaan "dalam ranah manakah seseorang harus dibiarkan bebas tanpa gangguan dari orang lain?" (Berlin, 2008). Para penganut gagasan kebebasan negatif percaya bahwa segala bentuk kekerasan boleh diterapkan demi mencegah kejahatan yang lebih parah, merupakan hal yang baik (Berlin, 2008). Menurutnya, seberapa buruknya terdengar kebebasan negatif, hal ini jarang diributkan masyarakat mayoritas karena salah satu tujuan kebebasan negatif yaitu tercapainya keamanan, status, dan kekuasaan (Berlin, 2008).

Lawan dari konsep kebebasan negatif yakni kebebasan positif. Kebebasan positif singkatnya dapat menjawab pertanyaan "apa, siapa, atau sumber apa yang menciptakan atau mengganggu kebebasan seseorang?" (Berlin, 2008). Para penganut gagasan kebebasan positif berfokus pada pencapaian diri. Bagi mereka, tujuan utama kebebasan yaitu bukan untuk menghindari gangguan eksternal, namun untuk lebih berfokus pada internal diri sendiri dengan digerakkan kesadarnya pribadi, dan untuk menjadi "master" dari diri sendiri (Berlin, 2008).

Seorang pemikir filosofi, Nancy J. Hirschmann menulis esai mengenai teori kebebasan positif menurut Isaiah Berlin dan kaitannya dengan feminisme. Hirschmann dalam esainya menganggap Berlin tidak mendukung feminisme karena Berlin bersekutu dengan beberapa filosofis yang menolak konsep kebebasan perempuan, serta tidak memberikan batasan struktural dari pilihan-pilihan perempuan. Namun, Hirschmann menggunakan konsep Berlin dalam menjelaskan batasan yang menempatkan perempuan selama berabad-abad. Hirschmann berargumentasi bahwa kebebasan positif diperlukan untuk memahami cara-cara di mana hasrat dihasilkan, dikonstruksi, dibatasi, dan ditingkatkan melalui relasi kuasa yang ada dalam konteks sosial kita. Hal ini berarti meskipun Berlin tidak secara langsung mendukung kebebasan perempuan, ia membantu membentuk konsep kebebasan yang pada akhirnya adalah untuk kepentingan para perempuan juga.

Terdapat banyak perdebatan mengenai batasan-batasan kebebasan negatif dan positif. Mayoritas masyarakat Indonesia setuju bahwa manusia harus menerima beberapa pembatasan kebebasan negatif demi menghindari kekacauan. Negara mewajibkan warganya untuk menaati peraturan dan undang-udang dirancang untuk membentuk ketertiban dan membantu mereka hidup bersama sehingga membuat fungsi masyarakat yang lebih lancar. Namun, terdapat juga masyarakat Indonesia yang bersikeras bahwa ada beberapa bidang kehidupan yang tidak boleh diatur, dan beranggapan bahwa individu harus memiliki kebebasan dalam ranah tertentu. Sebagai contoh, haruskah negara menempatkan pembatasan pada apa yang mungkin dikatakan atau baca, atau pada aktivitas seksual apa yang mungkin dilakukan oleh warga negaranya?

Sedangkan, kebebasan positif adalah kebebasan dari dikontrol oleh orang lain, kebebasan positif adalah kebebasan untuk mengendalikan diri. Misalkan seorang perokok yang tidak dapat menghentikan kebiasaan yang membahayakan kesehatannya. la bebas untuk menghentikan perilakunya ataupun sebaliknya. Karena konsep kebebasan positif adalah bebas untuk mengendalikan dirinya sendiri. Dalam konteks kebebasan positif perempuan, mereka bebas untuk menentukan nasibnya, memilih pekerjaannya, dan menuntut ilmu setinggi-tingginya.

\section{Simpulan}

Feminisme dilihat dari kacamata filosofi memiliki makna yang lebih dalam dari hanya sekadar protes akan kesetaraan dan kebebasan. Menurut Mary Wollstonecraft, kesenjangan antar gender dihasilkan dari pemberian edukasi dan pengalaman yang berbeda, sehingga menciptakan peran gender yang memunculkan stereotip bagaimana perempuan harus bertindak. Pendidikan seharusnya tidak mengenal gender, dan setiap individu berhak mendapatkan kebebasan untuk menempuh pendidikan setinggi-tingginya. Menurut Simone de Beauvoir, perempuan dan laki-laki tidak diciptakan sama namun seluruh individu harusnya memiliki hak dan kebebasan yang setara. Perempuan harus menemukan jati dirinya melalui kebebasan. Menurut Isaiah Berlin, terdapat kebebasan positif dan kebebasan negatif. Perempuan Indonesia masih sangat dibatasi kebebasannya. Terdapat kebebasan positif yaitu perempuan bebas menentukan nasib dan mengendalikan dirinya, dan terdapat kebebasan negatif yang melibatkan kepentingan banyak orang. Masih perlu dipertanyakan batasan-batasan kebebasan yang dapat diatur, dan kebebasan yang mutlak dimiliki para perempuan. Terkadang batasan ini bias sehingga masih banyak perempuan yang merasa dirinya terkekang. Untuk itu, gerakan feminisme sangat diperlukan di Indonesia. 


\section{Daftar Pustaka}

Beauvoir, Simone. 1949. The Second Sex. London: Jonathan Cape.

Berlin, Isaiah. 1970. Four Essays on Liberty. New York: Oxford University Press.

Berlin, Isaiah. 2008. Two Concepts of Liberty. Oxford: Oxford University Press. pg.166-217.

Harrison, Kevin \& Boyd, Tony. 2003. Understanding Political Ideas and Movements. Manchester and New York: Manchester University Press.

Kristeva, Julia. 1986. The Kristeva Reader. New York: Columbia University Press.

Lianawati, Ester. 2021. Beauvoir Melintasi Abad. D.I.Yogyakarta: Buku Mojok Group

Prameswari, N.P.L.M., Nugroho, W.B., \& Mahadewi, N.M.A.S. 2019. Feminisme Eksistensial Simone De Beauvoir: Perjuangan Perempuan di Ranah Domestik. Jurnal Ilmiah Sosiologi. 1 (2).

Therborn, Göran. 2004. Between Sex and Power: Family in The World, 1900-2000. London and New York: Routledge.

Tutupary, Victor Delvy. 2016. Kebebasan Kehendak (Free Will) David Ray Griffin Dalam Perspektif Filsafat Agama. Jurnal Fisafat. 26 (1).

Walby, Sylvia. 1990. Theorizing Patriarchy. Oxford: Blackwell.

Weitz, Rose. 2003. The Politics of Women's Bodies: Sexuality, Appearance, and Behavior. New York: Oxford University Press.

Wollstonecraft, Mary. 1989. The Works of Mary Wollstonecraft. New York: New York University Press, Volume V - VI.

Wollstonecraft, Mary. 1995. A Vindication of the Rights of Men, in a Letter to the Right Honourable Edmund Burkell. Political Writings of the 1790s. London: Pickering, pg. 11-58. 